\title{
THE EFFECT OF NITROGEN DEPOSITION AND EDAPHIC CONDITIONS ON MICROBIAL ACTIVITIY IN THE ALPINE ZONE OF THE GRAND TETON NATIONAL PARK
}

\author{
Helga VAn Miegroet $\downarrow$ DePartment of Wildland Resources \& ECOLOGY \\ CENTER — UTAH STATE UNIVERSITY — LOGAN
}

\section{$\downarrow$ INTRODUCTION}

Atmospheric nitrogen $(\mathrm{N})$ deposition rates show increasing $\mathrm{N}$ loadings since the $1980 \mathrm{~s}$ in the western U.S. associated with increasing $\mathrm{N}$ emissions from industrial, urban, and agricultural sources (Fenn et al., 2003). Compared to the eastern U.S., the number of NADP/NTN (National Atmospheric Deposition Program/ National Trends Network) and CASTNet (Clean Air Status Network) monitoring sites is much more limited in the west, and they are rarely located in the highestelevations, where ecosystems are likely to be more sensitive (Burns 2004). Although N deposition tends to increase with elevation in this region (Williams and Tonnesen 2000), there are considerable uncertainties about the actual N deposition levels in the Rocky Mountains. Modelsimulations indicate a "hotspot" of $\mathrm{N}$ deposition near Grand Teton National Park (GRTE) (Fenn et al., 2003; Nanus et al. 2003), with feedlot and fertilizer $\mathrm{N}$ emissions in Southern Idaho, as potential sources impacting the alpine communities in GRTE. However, little data is currently available on the actual atmospheric $\mathrm{N}$ inputs to alpine ecosystems in GRTE, either as snow during winter or wet and dry deposition during the short snow-free period.

Alpine communities are considered very sensitive to changes in $\mathrm{N}$ deposition because a combination of short growing seasons, shallow and poorly developed soils, steep terrain, sparse vegetation, and low rates of primary productivity generally limit the $\mathrm{N}$ retention capacity of the ecosystem (Fisk et al., 1998; Burns, 2004). These ecosystems are generally considered to be $\mathrm{N}$ limited (Burns 2004), and increases on $\mathrm{N}$ availability may be reflected in changes in vegetation composition, biomass, and $\mathrm{N}$ content, as well as in changes in soil $\mathrm{N}$ status and belowground processes (Bowman et al., 1995). Earlier work at Niwot Ridge in the Colorado Front Range has indicated that the $\mathrm{N}$ cycling response to changes in $\mathrm{N}$ inputs is greatly influenced by soil climate, especially soil moisture and temperature (Bowman et al., 1993; Fisk and Schmidt, 1995; Fisk et al., 1998). In ecosystems where precipitation mostly falls as snow (such as in GRTE), soil temperature and moisture regime is strongly influenced by the timing, thickness, duration, and redistribution of the snowpack (Brooks et al., 1996; Fisk et al., 1998; Van Miegroet et al., 2000).

Because alpine ecosystems may become $\mathrm{N}$ saturated (i.e., lose their capacity to effectively retain $\mathrm{N}$ ) with relatively small changes in atmospheric $\mathrm{N}$ deposition (Baron et al., 2000), there is great interest in identifying early indicators of ecosystem change in response changes in atmospheric $\mathrm{N}$ inputs, and establishing critical $\mathrm{N}$ loads that can be tolerated by these systems. Most recently, Bowman and coworkers (Bowman et al. 2006) suggested that vegetation changes will precede detectable changes in soil $\mathrm{N}$ parameters, based on $\mathrm{N}$ addition experiments at Niwot Ridge. 
Our research in GRTE is intended to verify the generality of these earlier findings, and test whether soil vs plant parameters are the most sensitive indicators of changes in ecosystem $\mathrm{N}$ status.

The overall objective of this two-year project is to assess the impact of atmospheric $\mathrm{N}$ deposition on the structure and function of alpine ecosystems in Grand Teton National Park (GRTE), based on field measurements and experimental manipulation of $\mathrm{N}$ loadings in alpine sites with contrasting (wet/dry) edaphic conditions and assumed $\mathrm{N}$ input regimes. Specific tasks in year one were to determine atmospheric $\mathrm{N}$ inputs and $\mathrm{N}$ status of a series of sites based on plant and soil parameters. To date relatively little is known about the belowground processes, and in this one-year subproject we collected baseline information on microbial biomass and nitrification potential across the $\mathrm{N}$ deposition and soil microclimate matrix. We hypothesized that edaphic conditions control overall abundance of microbial populations, whereas current $\mathrm{N}$ deposition and site $\mathrm{N}$ status influence the abundance of nitrifier populations and nitrification potential.

\section{$\uparrow$ METHODS}

To test the influence of $\mathrm{N}$ deposition and edaphic conditions on above- and belowground $\mathrm{N}$ pools and $\mathrm{N}$ dynamics, we established a series of plots along a modeled $\mathrm{N}$ deposition gradient in GRTE. Based on access via existing trail system, three candidate sites were identified: Moose Basin (High), Paintbrush Canyon /Mica Lake (Low) and Rendezvous Mountain (Medium/Low).

\section{Plot layout}

Within each of the three $\mathrm{N}$ deposition areas, plots were established in summer 2006 at three sites (located within 0.50 miles from each other) where contrasting edaphic conditions existed (wet vs dry) due to differential snowpack retention. This yielded a two-factorial set-up of initial conditions ( $3 \mathrm{~N}$ deposition levels, 2 edaphic conditions) replicated three times for a total of 18 site locations for which background information on $\mathrm{N}$ deposition, site microclimate, vegetation, and soils was collected. Each site was georeferenced by GPS. At each of the 18 site locations two adjacent $2.5 \mathrm{~m}$ by $2.5 \mathrm{~m}$ plots will be delineated separated by a $1-\mathrm{m}$ buffer zone. These plots will be assigned as either control or $+\mathrm{N}$ treatment in the year two of this project.

\section{$\mathbf{N}$ deposition measurements}

In early spring 2006, at maximum snow accumulation, snow surveys were conducted at Moose Basin and Rendezvous Mountain in collaboration with the USGS. Due to logistical constraints, no snow survey was collected at Mica Lake. Snow depth, snow water equivalent and chemical composition were determined. We were unable to repeat the snow survey in 2007 due to early melt of the snow pack and avalanche hazard that prohibited access to the sites.

$\mathrm{N}$ input during the snowfree period was measured at each of the 18 plot pairs, using ion exchange resin funnels left in the field between 1.5 and 2.5 months (Fenn and Poth, 2004). Resins were retrieved at the end of the field season, extracted with $2 \mathrm{~N} \mathrm{KCl}$, and the extractant analyzed for $\mathrm{NH}_{4}-\mathrm{N}$ and $\mathrm{NO}_{3}-\mathrm{N}$.

To capture the combined $\mathrm{N}$ input from snowmelt and wet+dry deposition during the snowfree period, PVC tubes with ion exchange resins were placed close to the ground in early summer 2006 (Susfalk and Johnson, 2003). They will be retrieved in summer 2007 and extracted as described above.

\section{Vegetation Characteristics}

Vegetation composition, species richness, aboveground biomass and $\mathrm{N}$ content were determined by floristic surveys and destructive sampling in all 36 plots. Vegetation composition and species richness was determined by identifying plant species and accounting for percent cover of each plant within a $1 \mathrm{~m} \times 1 \mathrm{~m}$ subplot located within the $2.5 \mathrm{~m} \times 2.5 \mathrm{~m}$ plot. Total percent cover for the entire $1 \mathrm{~m} \times 1 \mathrm{~m}$ plot was then assessed including percent bare ground and percent rock. Aboveground plant biomass was determined by clipping vegetation within two 25 $\mathrm{cm}$ by $25 \mathrm{~cm}$ frames, drying the materials at $65^{\circ} \mathrm{C}$ and weighing it. Subsamples were ground and analyzed for $\mathrm{N}$ and $\mathrm{C}$ using LECO combustion. Belowground biomass and $\mathrm{N}$ content was determined from soil cores $(0-15 \mathrm{~cm}$ depth; 1 per plot), by manually separating roots and analyzing ground biomass for $\mathrm{N}$ as described above. Chemical and statistical analysis of the vegetation data is still in progress.

\section{Soil characteristics}

Several cores $(0-15 \mathrm{~cm}$ length, $5 \mathrm{~cm}$ 
diameter) were taken in each plot to determine bulk density, root biomass, soil moisture content, total and extractable inorganic N, soil nitrification potential and microbial biomass.

Inorganic soil $\mathrm{N}$ content in the upper soil was determined by extracting homogenized soil samples with $2 \mathrm{~N} \mathrm{KCl}$ in the field (Van Miegroet, 1995) and analyzing extractant for $\mathrm{NH}_{4}-\mathrm{N}$ and $\mathrm{NO}_{3}-\mathrm{N}$. All concentrations are expressed on a dry weight basis using gravimetric soil moisture content measurements on subsamples with rock an debris removed and dried at $105^{\circ} \mathrm{C}$.

Soil cores to be used for microbial properties were transported from the field to the lab in coolers and kept refrigerated until processing within 3 days after collection.

Microbial biomass on soil samples taken at each location was determined by standard extraction-fumigation methods (Brookes et al., 1985), and total organic carbon (TOC) analysis of fumigated and unfumigated soils. To date, TOC analysis is still in progress, and no results on microbial biomass will be reported here.

Nitrification potential was determined by incubating $8 \mathrm{~g}$ of fresh soil soils $50 \mathrm{ml}$ plastic test tubes placed in a constant-temperature incubator $\left(\sim 25{ }^{\circ} \mathrm{C}\right)$ for 60 days, extracting subsamples after $30\left(\mathrm{t}_{1}\right)$ and 60 days $\left(\mathrm{t}_{2}\right)$ with $2 \mathrm{~N}$ $\mathrm{KCl}$, and analyzing extractant for $\mathrm{NO}_{3}-\mathrm{N}$ as described above. Changes in $\mathrm{NO}_{3}-\mathrm{N}$ concentration relative to in-field extraction $\left(\mathrm{t}_{0}\right)$, expressed on a soil dry weight basis, were used as a relative index of nitrification potential.

\section{Soil Microclimate}

Soil temperature will be measured continuously at each of the 18 locations using miniature data loggers (StowAway Tidbits Onset Computer Corp), installed within the 1-m buffer zone between $5-15 \mathrm{~cm}$ depth, programmed to record temperature at 1 to 2-hour interval, and downloaded at the beginning and end of the snowfree period. Soil moisture regime is determined using 10-cm long soil moisture probes (Decagon $\mathrm{ECH}_{2} \mathrm{O}$ probes) installed vertically under the soil surface in the $1-\mathrm{m}$ buffer zone. Periodic measurements were taken in the summer of 2006 using a portable readout device. At six locations (1 replicate per $\mathrm{N}$ deposition- edaphic combination) these probes will be hooked up to a datalogger (Decagon EM5 Datalogger), and soil moisture readings recorded continuously at preset intervals. They will be downloaded during in summer 2007 using a PDA.

\section{$\downarrow \quad$ RESULTS}

\section{N Deposition Inputs}

Results from the 2006 snow survey at Moose Basin and Rendezvous confirm the modeled $\mathrm{N}$ deposition gradient (Nanus et al., 2003) with higher atmospheric $\mathrm{N}$ inputs to the north of the Park (Moose Basin) and lower levels to the south (Rendezvous) (Figure 1). Inorganic $\mathrm{N}$ inputs as snow range between 1 and $2 \mathrm{~kg} \mathrm{~N}$ ha ${ }^{1}$ with a slightly greater proportion entering as $\mathrm{NH}_{4}-\mathrm{N}$ (Figure 1 and 2). Summer $\mathrm{N}$ inputs as determined with resin tube collectors deployed for 40 to 90 days in summer 2007 (Fenn and Poth, 2004) do not appear to differ among locations (Figure 3). The summer input data are still preliminary; but accounting for incomplete resin adsorption efficiency and extending the data to the total snow free period, we estimate an additional input of $\sim 0.5 \mathrm{~kg} \mathrm{~N} \mathrm{ha}^{-1}$ in summer, again with a slightly higher proportion entering in $\mathrm{NH}_{4}$ form. Differences in $\mathrm{N}$ deposition among the sites appear to be determined by snow accumulation, rather than differences in dry deposition during summer.

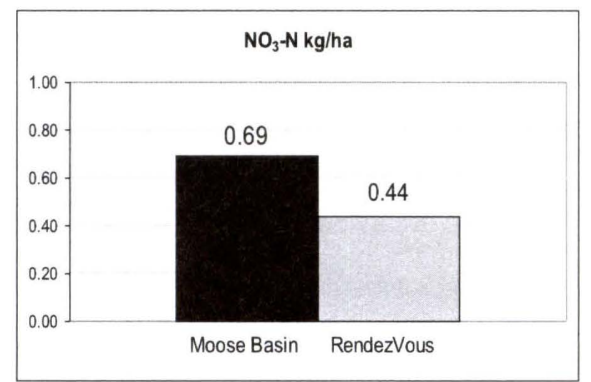

(A)

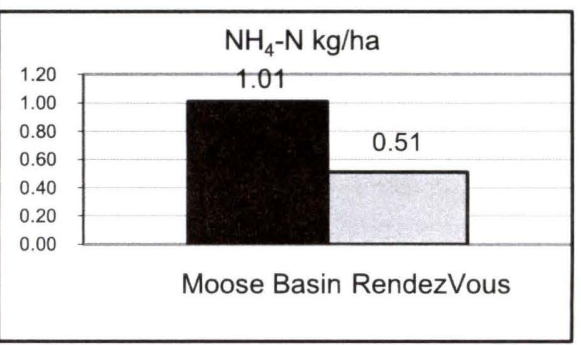

(B)

Figure 1. Nitrate and Ammonium input ( $\mathrm{kg} / \mathrm{ha})$ determined from 2006 snow survey at Moose Basin and Rendezvous Mountain. 


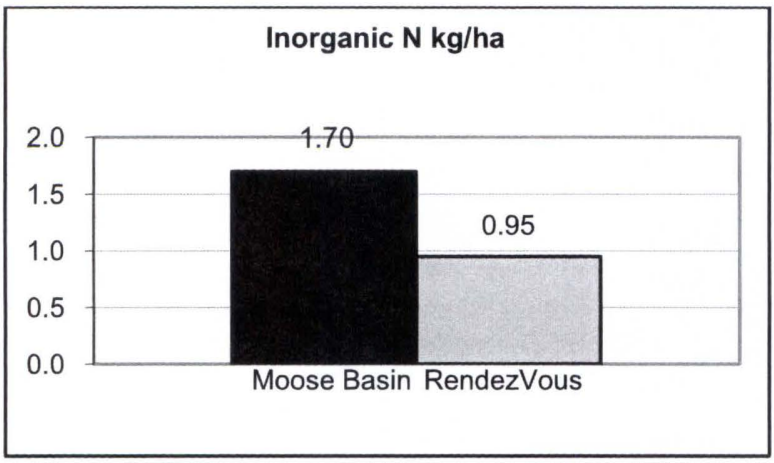

Figure 2. Total inorganic $\mathrm{N}$ input as snow in Winter 2006 at the northern and southern part of the Grand Teton National Park.

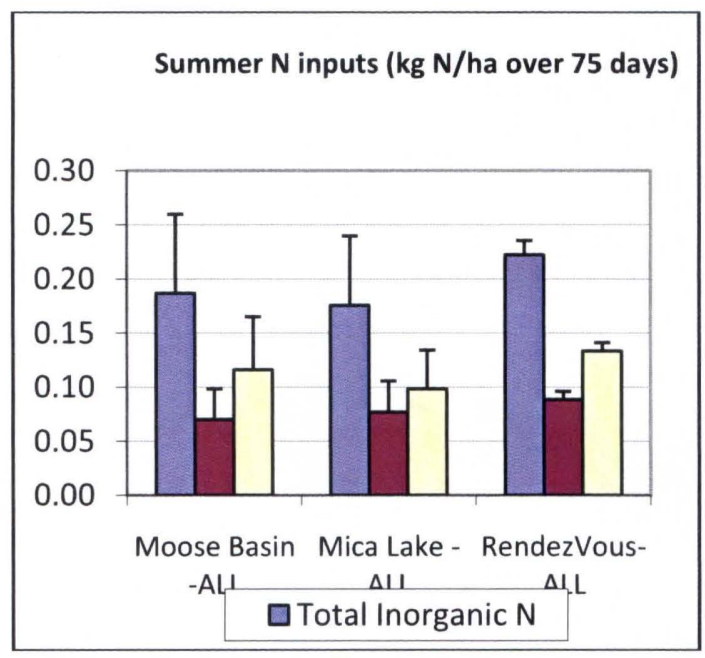

Figure 3. Atmospheric $\mathrm{N}$ deposition captured by resin collectors in summer 2007 at the three alpine locations.

\section{Soil Nitrogen Status}

There are marked differences in the static and dynamics indicators of soil $\mathrm{N}$ status among the three sampling locations. Extractable inorganic soil $\mathrm{N}$ is highly variable among locations and edaphic conditions at each sampling location, ranging from $0-10 \mu \mathrm{g} \mathrm{g}^{-1}$ (Figure 4 and 5). Total inorganic $\mathrm{N}$ and initial $\mathrm{NO}_{3}-\mathrm{N}$ concentration do not follow the observed and modeled $\mathrm{N}$ deposition gradient and are generally lower at Moose Basin (Figure 4 and 5). At that site, differences in initial $\mathrm{NO}_{3}-\mathrm{N}$ concentration between wet and dry sites are also smaller. At the Mica Lake and Rendezvous sites, differences between edaphic conditions are more pronounced, with higher initial soil $\mathrm{NO}_{3}-\mathrm{N}$ concentrations observed at the wetter sites (Figure 5).
The nitrification potential, indicative of the size and activity of the nitrifier population, differs substantially among the three locations and appears to follow the $\mathrm{N}$ deposition gradient. Despite initial site exhibits the highest nitrification potential, which is sustained during the 60-days aerobic laboratory incubation (Figure 6). In contrast, nitrification production rates remain low throughout the intire incubation time at Rendezvous (low N site), irrespective of edaphic conditions (Figure 6 and 7). Edaphic conditions also influence the nitrification potential, but the direction and magnitude varies among sites. Whereas wetter conditions favor higher nitrification potential at the low $\mathrm{N}$ input site (Mica Lake, Rendezvous), the opposite is true at the higher $\mathrm{N}$ input site (Moose Basin), where higher nitrification potentials were measured in soil from dry sites (Figure 7). Our data indicate the differences in $\mathrm{N}$ inputs and edaphic conditions interact to influence nitrification potential.

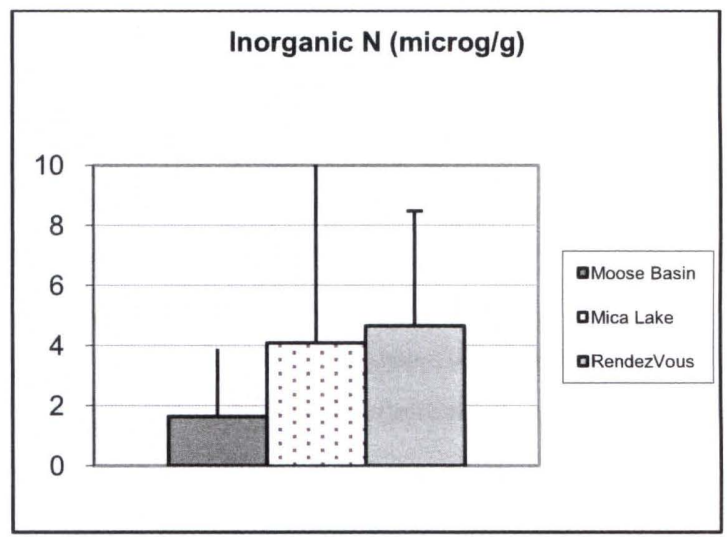

Figure 4. Average extractable inorganic $\mathrm{N}$ soil concentration ( $\mu \mathrm{g}$ per $\mathrm{g}$ dry soil) at the three alpine sites.

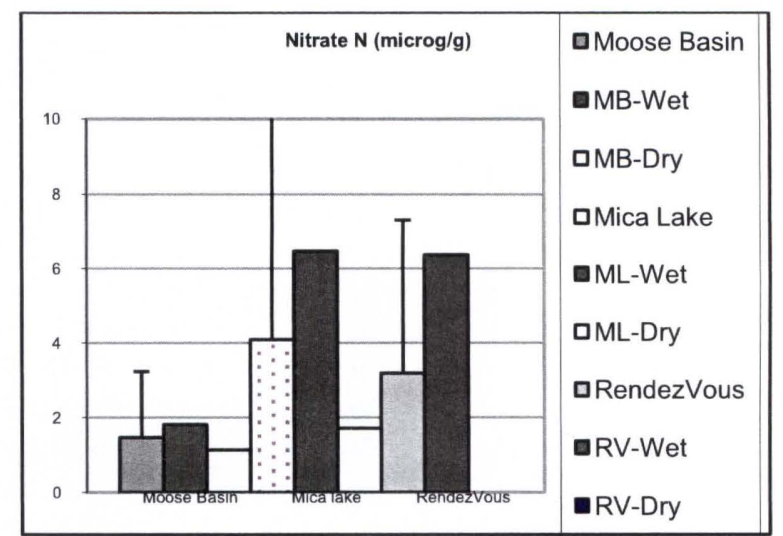

Figure 5. Average extractable $\mathrm{NO}_{3}-\mathrm{N}$ concentration ( $\mu \mathrm{g}$ per $\mathrm{g}$ dry soil) and difference between wet and dry sites at the three alpine sampling locations. 


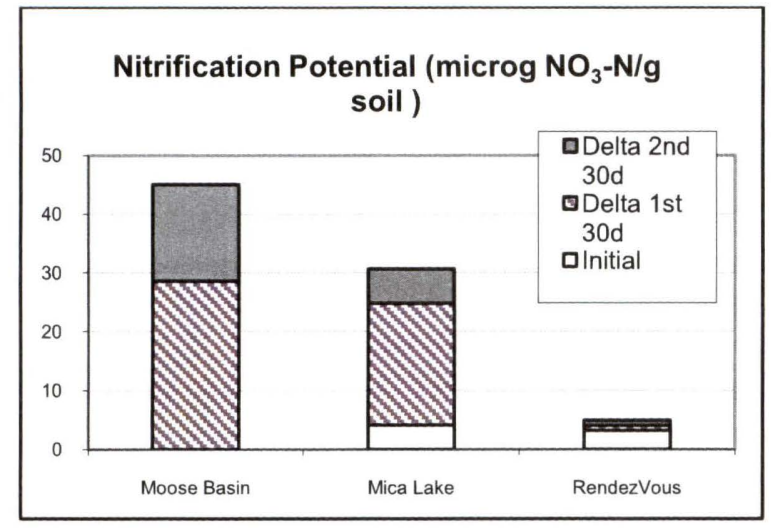

Figure 6. Average nitrification potential after 30 and 60 days of incubation of surface soils from the three alpine locations.

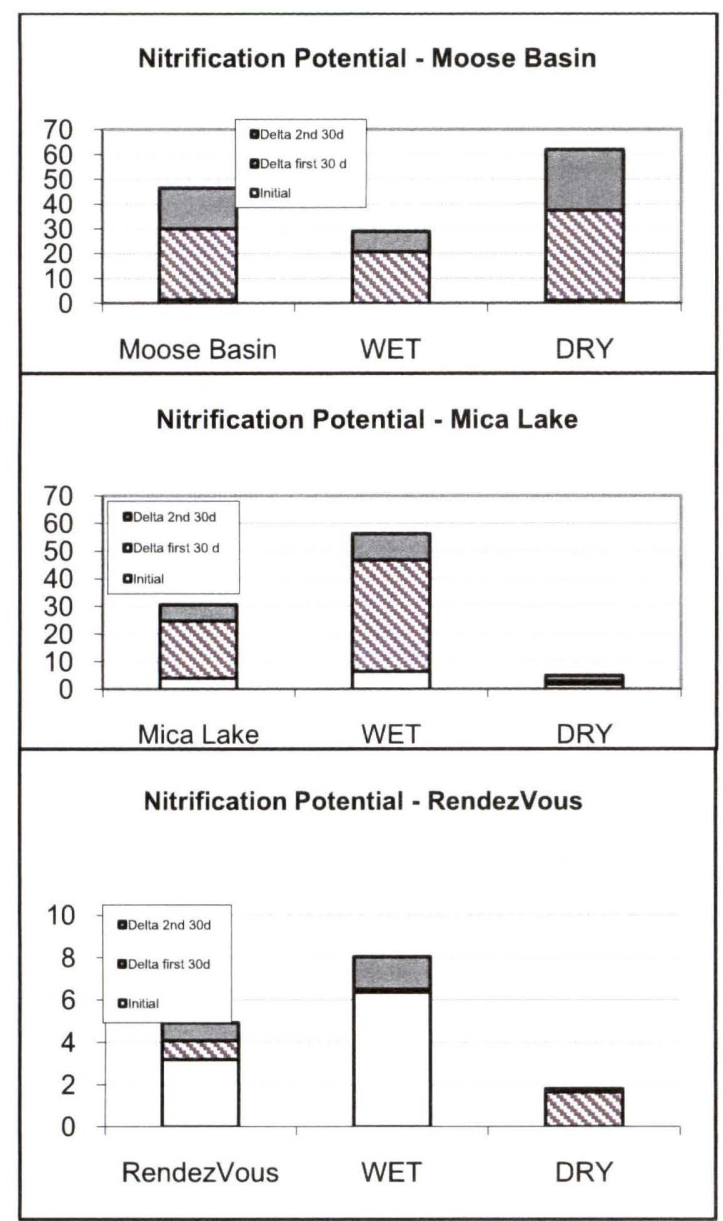

Figure 7.Nitrification potential after 30 and 60 days of incubation of surface soils sampled at dry and wet sites in the three alpine locations.

\section{$\downarrow \quad$ CONCLUSIONS}

Our preliminary data indicate that (1) N deposition inputs to the alpine zone of the Grand Teton National Park are generally low; (2) there is indeed a $\mathrm{N}$ deposition gradient; and (3) that there are detectable differences in $\mathrm{N}$ dynamics among $\mathrm{N}$ input sites that are further modified by local edaphic conditions. While static soil parameters (e.g., extractable inorganic $\mathrm{N}$ ) reflect differences in edaphic conditions (wet-dry), they do not appear to be good indicators changes in $\mathrm{N}$ deposition. Microbial soil parameters (e.g., nitrification potential) on the other hand, are more sensitive indicators of changes in soil function due to a combination of $\mathrm{N}$ deposition and soil moisture regime. This study indicates that even small differences in $\mathrm{N}$ input $(<1 \mathrm{~kg} \mathrm{~N}$ $\left.\mathrm{ha}^{-1} \mathrm{yr}^{-1}\right)$ can result in detectable differences in soil nitrifier population, and thus in the ability of soils to respond to increases in $\mathrm{N}$ inputs through accelerated $\mathrm{NO}_{3}$ formation.

\section{$\downarrow \quad$ Literature Cited}

Baron, J.S., H.M. Rueth, A.M. Wolfe, K.R. Nydick, E.J. Allstott, J.T. Minear, B. Moraska. 2000. Ecosystem response to nitrogen deposition in the Colorado Front Range. Ecosystems 3: 352-368.

Brookes, P.C., A. Landman, G. Pruden, and D. Jenkinson. 1985. Chloroform fumigation and the release of soil nitrogen: a rapid extraction method to measure microbial biomass nitrogen in soil. Soil Biology and Biochemistry 17: 837-842.

Brooks, P.D., M.W. Williams, S.K. Schmidt. 1996. Microbial Activity Under Alpine Snowpacks, Niwot Ridge, Colorado. Biogeochemistry 32:93-113.

Burns, D.A. 2004. The effect of atmospheric nitrogen deposition in the Rocky Mountains of Colorado and southern Wyoming, USA - a critical review. Environmental Pollution 127: 257-269. 
Bowman, W.D., T.A. Theodose, and M.C. Fisk. 1995. Physiological and production responses of plant growth forms to increases in limiting resources in alpine tundra: implications for differential community response to environmental change. Oecologia 101:217-22.

Bowman, W.D., J.R. Gartner, K. Holland and M. Wiederman. 2006. Nitrogen crucial loads for alpine vegetation and terrestrial ecosystem response: are we there yet? Ecological Applications 16: 1183-1193.

Bowman, W.D., T.A. Theodose, J. Schardt, and R.T. Conant. 1993. Constraints of nutrient availability on primary production of two alpine tundra communities. Ecology 74(7): 2085-2097.

Fenn, M.E. and M.A. Poth. 2004. Monitoring nitrogen deposition in throughfall using ion exchange resin columns: a field test in the San Bernardino mountains. Journal of environmental quality 33: 2007-2014.

Fenn. M.E., R. Haeuber, G.S. Tonnesen, J.S. Baron, S. Grossman-Clarke, D. Hope, D.A. Jaffee, S.Copeland, L. Geiser, H.M. Rueth and J.O. Sickman. 2003. Nitrogen emissions, deposition, and monitoring in the Western United States. BioScience 53(4) 391-403.

Fisk, M.C. and S.K. Schmidt. 1995. Mitrogen Mineraliza6tiona nd Microbial Biomass Nitrogen Dynamics in Three Alpine Tundra Communities. Soil Sci Am J 59:1036-1043.
Fisk, M.C., S.K. Schmidt and T.R. Seastedt. 1998. Topographic patterns of aboveand belowground production and nitrogen cycling in alpine tundra. Ecology 79: 2253-2266. Nanus, L., D. Campbell, G. Ingersoll, D. Clow and M.A. Mast. 2003. Atmospheric deposition maps for the Rocky Mountains. Atmospheric Environment 37: 4881-4892.

Susfalk, R.B. and D.W. Johnson. 2002. Ion exchange resin based soil solution lysimeters and snowmelt solution collectors. Communications in Soil Science and Plant Analysis 33 (7\&8):1261-1275.

Van Miegroet, H. 1995. Inorganic nitrogen determined by laboratory and field extractions of two forest soils. Soil Science Society of America Journal 59:549-553.

Van Miegroet, H., M.T. Hysell, and A. Denton Johnson. 2000. Soil microclimate and chemistry of spruce-fir tree islands in Northern Utah. Soil Science Society of America 64: 1515-1525.

Williams, M. and K. Tonnessen. 2000. Critical loads for inorganic nitrogen deposition in the Colorado Front Range, USA. Ecological Applications 10(6): 16481665. 